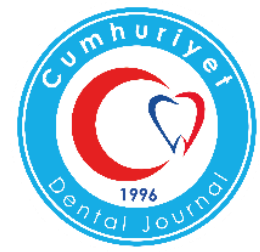

\title{
COMPARING THE INTUBATION EFFECTIVENESS OF TWO DIFFERENT LARYNGOSCOPES IN PATIENTS WITH CEREBRAL PALSY
}

\author{
Serebral Palsili Hastalarda İki Farklı Laringoskopun Entübasyon Etkinliğinin \\ Karşılaş̧ırılması
}

\author{
Aysun ÇAĞLAR TORUN ${ }^{1}$, Mustafa Erhan $\mathrm{SARI}^{2}$, Ersin $\mathrm{KÖKSAL}^{3}$, Sevgin İBİş ${ }^{4}$
}

\author{
Makale Kodu/Article Code $\quad$ : 397203 \\ Makale Gönderilme Tarihi $\quad$ : 20.02.2018 \\ Kabul Tarihi \\ $: 17.05 .2018$
} \begin{abstract}
Objective: In patients with expected airway difficulties, specific preparatory and auxiliary equipment is required before general anesthesia. The aim of this study was to compare the intubation efficacy of Macintosh laryngoscope with that of the McGrath MAC video laryngoscope in patients with cerebral palsy.

Materials and Methods: The study was conducted in forty patients (aged 4-15) with cerebral palsy who were scheduled to undergo dental treatment. Intubations were performed in patients randomly assigned to the McGrath MAC video laryngoscope or the Macintosh laryngoscope. The characteristics of the patients mean arterial blood pressure, heart rate, end-tidal carbon dioxide, and peripheral oxygen saturation were measured. The intubation success, intubation time, Cormack and Lehane grades, number of trials, need for neck extension, and complications were recorded. An independent sample $t$-test and a Mann-Whitney $U$ test were used. A chi-square test was used for the analysis of categorical data. The level of statistical significance was accepted as $p<$ 0.05 .
\end{abstract}

Results: When both groups were compared in terms of the glottic view, intubation time, and need for neck extension, there was no significant difference $(p=0.542, p=0.779$, and $p=$ 1.000 , respectively). All the intubations were performed successfully at the first attempt in both groups, and no complications were recorded.

Conclusion: Although our study included patients with cerebral palsy, in which musculoskeletal anomalies are common, sufficient muscle relaxation for intubation after general anesthesia was achieved in all the patients. There was no evidence of intubation difficulty in either group of patients, and cerebral palsy, with its existing deformities, did not affect the intubation success or complication rate. No additional advantages of using video laryngoscopy in patients with cerebral palsy were found.

Keywords: intubation, video laryngoscope, macintosh laryngoscope, cerebral palsy.

\section{öz}

Amaç: $\mathrm{Bu}$ çalışmanın amacı serebral palsili hastalarda, Macintosh laringoskop ile McGrath MAC video laringoskopun entübasyon etkinliğini karşılaştırmaktır.

Gereç ve yöntem: Çalışmaya serebral palsili ve diş tedavisi planlanan 40 hasta dahil edildi. Hastalar rastgele McGrath MAC video laringoskop veya Macintosh laringoskop ile entübe edildi. Hastaların demografik özellikleri, ortalama arteryel kan basıncı, kalp hızı, end-tidal karbondioksit ve periferik oksijen satürasyonu ölçüldü. Entübasyon başarısı, entübasyon zamanı, Cormack ve Lehane siniflamas1, deneme sayıs1, boyun ekstansiyon ihtiyacı ve komplikasyonlar kaydedildi. Bağımsız örneklem t testi ve Mann-Whitney U testi kullanıldı. Kategorik verilerin analizi için ki-kare testi kullanıldı. İstatistiksel anlamlılık düzeyi $\mathrm{p}<0,05$ olarak kabul edildi.

Bulgular: Glottik görüntü, entübasyon zamanı ve boyun ekstansiyon ihtiyacı açısından karşılaştırıldığında iki grup arasında anlamlı fark bulunamadı $(\mathrm{p}=0.542, \mathrm{p}=0.779$ ve $\mathrm{p}=$ 1.000). Tüm entübasyonlar her iki gruptaki ilk girişimde başarıyla uygulandı ve herhangi bir komplikasyon kaydedilmedi.

Sonuç: Her iki gruptaki hastalarda entübasyon güçlüğü olduğuna dair bir bulguya rastlanmamıstır ve mevcut deformiteleri serebral palsili hastaların entübasyon başarısını veya komplikasyon oranını etkilememiştir. Serebral palsili hastalarda video laringoskop kullanmanın ek bir avantajı tespit edilememiştir.

Anahtar kelimeler: entübasyon, video laringoskop, macintosh laringoskop, serebral palsi.

\footnotetext{
${ }^{1}$ Anesthesia Specialist, MD, Ondokuz Mayis University, Faculty of Dentistry, Department of Oral and Maxillofacial Surgery, Samsun, Turkey.

${ }^{2}$ Ondokuz Mayis University, Faculty of Dentistry, Department of Pediatric Dentistry, Samsun, Turkey.

${ }^{3}$ Anesthesia Specialist, MD, Ondokuz Mayis University, Faculty of Medicine, Department of Anesthesiology, Samsun, Turkey.

${ }^{4}$ Specialist dentist, Bafra Dental Health Center, Samsun.
} 


\section{INTRODUCTION}

Cerebral palsy occurs in the developing brain as the result of a nonprogressive lesion. With age, patients with cerebral palsy may develop long-term motor function, posture, and movement development disorders, limiting their activities. ${ }^{1}$ This may result in increased spasticity and rigidity in muscles and lead to musculoskeletal abnormalities. Therefore, oral care is more difficult in patients with cerebral palsy and periodontal health is affected negatively. As a result, many dental problems are encountered. When appropriate conditions are provided for patients with cerebral palsy, local anesthesia can be used for dental treatment. Difficulty in cooperation and the number of teeth in need of treatment often means these patients require general anesthesia. $^{2}$

In particular the limitation of neck movements, chest deformities, secondary joint contractures and dislocations, all of which result in excessive activation of the spastic muscles, are common musculoskeletal anomalies. ${ }^{3,4}$ These features may result in difficulties with intubation and may be experienced during the administration of general anesthesia in patients with cerebral palsy. ${ }^{5}$ Depending on the degree of airway management problems there is a risk of complications, such as airway trauma, hypoxia-induced brain injury, myocardial damage, and death. ${ }^{6,7}$ In patients with such expected airway difficulties, specific preparatory and auxiliary equipment is required before general anesthesia.

In recent years, several clinical and simulated studies have investigated the efficacy of video laryngoscopes in the management of difficult airways., ${ }^{8,9}$ Many studies have shown that video laryngoscopy facilitates the intubation process in patients with a difficult airway compared to conventional laryngoscopy. ${ }^{10,11}$ However, the literature lacks studies of the use of video laryngoscopy in patient groups such as those with cerebral palsy, who have a risk of a difficult airway and may often need general anesthesia. For this reason, this study was planned with the assumption that video laryngoscopy improves the success of intubation in patients with cerebral palsy. The aim of this study was to compare the intubation efficacy of a traditional Macintosh laryngoscope with that of the McGrath MAC video laryngoscope in patients with cerebral palsy.

\section{MATERIALS AND METHODS}

\section{Study design}

This was a prospective, randomized clinical study approved by the Ondokuz Mayis University Clinical Research Ethics Committee. Forty patients (aged 4-15) scheduled to undergo dental treatment at the pediatric dental clinic with an ASA score of I or II were included in the study. Intraoral examination and dental treatment planning were done in patients who did not have cooperative difficulties. The non-cooperative patient group was examined during general anesthesia and treated. Patients with severe systemic disease, a history of difficult intubation or laryngoscopy, or an allergy to the anesthetics to be used in the procedure were excluded from the study. All relatives of the patients were informed about the procedure and signed informed consent forms. All tracheal intubations were performed by the same anesthetist who was familiar with video laryngoscopes and had extensive experience in using these devices.

In the preoperative examination demographic data, limitations in neck and jaw movements and chest deformities were recorded. Patients with a mouth corner-tragus line angle with a horizontal line of $<80^{\circ}$ were considered as having limited neck movement. Patients with an oral inter-incisor distance pf $<2 \mathrm{~cm}$ were considered as having restricted jaw movement. Kyphosis, scoliosis, and kyphoscoliosis were recorded as chest deformities. ${ }^{12}$ 
An infusion of $0.9 \%$ sodium chloride was started after the patient was placed on the operating table and vascular access was established. The patients were monitored and their mean arterial blood pressure, heart rate, end-tidal carbon dioxide, and peripheral oxygen saturation (SpO2) were measured. Before induction (baseline), after induction, after intubation, and 1, 3, and 5 min after intubation values were recorded. The induction of anesthesia was achieved with $1 \mu \mathrm{g} / \mathrm{kg}$ of fentanyl and $1-3 \mathrm{mg} / \mathrm{kg}$ of propofol intravenously. After confirmation of face mask ventilation, all the patients received rocuronium $(0.6 \mathrm{mg} / \mathrm{kg})$ intravenously. Anesthesia was maintained with $50 \%$ nitrous oxide in oxygen and sevoflurane $2 \%$ via inhalation.

The patients were randomly assigned via the closed envelope method to two groups, depending on the type of intubation procedure. Intubation was performed with the McGrath MAC video laryngoscope in the video group (Figure 1) and with the Macintosh laryngoscope in the Macintosh group. In the McGrath MAC group, primary direct laryngoscopy using a Macintosh laryngoscope size 2 was performed to assess the glottic view according to the Cormack-Lehane (C-L) grading system. ${ }^{13}$

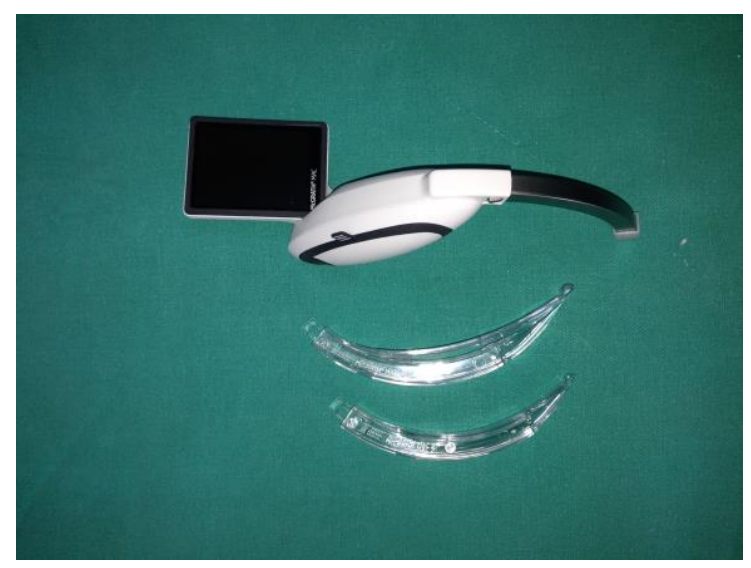

Figure 1. McGrath MAC video laryngoscope

After this initial laryngoscopy, the trachea was intubated with the McGrath MAC video laryngoscope, and the $\mathrm{C}-\mathrm{L}$ grade of the glottic view was recorded. In the Macintosh group, the C-L grade was also documented.
Tracheal intubation attempts longer than $60 \mathrm{sec}$. were deemed unsuccessful. ${ }^{14}$ In both groups, three attempts were allowed for tracheal intubation. After three unsuccessful attempts, the tracheal intubation was deemed unsuccessful, ${ }^{15}$ and an alternative approach was used by applying the difficult airway algorithm method. ${ }^{16}$ The trial numbers were recorded. Time from the insertion of the laryngoscope into the mouth until the end-tidal carbon dioxide value registered on the screen was recorded as the intubation period in both groups. ${ }^{17}$ The need for neck extension during tracheal intubation was also recorded.

Blood trails in the mouth or on the lips, used instruments, or any tooth damage were recorded as complications.

\section{Statistical analysis}

The data were analyzed with the IBM SPSS V21 program. The normality of the data was evaluated with a Shapiro-Wilk test. An independent sample $t$-test and a MannWhitney $U$ test were used. A chi-square test was used for the analysis of categorical data. The results are presented as the arithmetic mean \pm standard deviation, and median (min$\max$ ) form. As a power analysis based on a previous study ${ }^{18}$ suggested, a sample size of 20 patients for each group was required to achieve a power of 1,000. The level of statistical significance was accepted as $p<0.05$.

\section{RESULTS}

There were no significant differences between the groups in relation to patients' characteristics (Table 1).

Table 1. Characteristics of patients.

\begin{tabular}{lccc}
\hline & $\begin{array}{c}\text { McGrath MAC } \\
(\mathbf{n}=\mathbf{2 0})\end{array}$ & $\begin{array}{c}\text { Macintosh } \\
(\mathbf{n}=\mathbf{2 0})\end{array}$ & p value \\
\hline Age (yr) & $11(4-15)$ & $12(4-14)$ & 0.089 \\
Gender (F/M) & $12 / 8$ & $7 / 13$ & 0.205 \\
Duration of operation (min.) & $50(30-110)$ & $50(30-120)$ & 0.211 \\
Chest deformity patients & 4 & 1 & 0.342 \\
Limited neck movement & none & none & - \\
Limited jaw movement & none & none & - \\
\hline Abbreviations: F; female, M; male. Data presented as median \\
(minimum-maximum).
\end{tabular}

The after induction, after intubation, and 1, 3, and 5 min after intubation $\mathrm{SpO} 2$ values were 
significantly higher in the McGrath MAC group ( $p=0.002, p=0.005, p=0.033, p=0.049$, and $p=0.015$, respectively). However, in both groups the $\mathrm{SpO} 2$ value was in the normal range. Other hemodynamic parameters were not significantly different (Table 2).

Table 2. Comparison of hemodynamic changes of patients.

\begin{tabular}{|c|c|c|c|c|c|c|}
\hline & Baseline & $\begin{array}{l}\text { Post } \\
\text { induction }\end{array}$ & $\begin{array}{l}\text { Post } \\
\text { layngoscopy }\end{array}$ & $\begin{array}{l}\text { AI } \\
\text { 1.min } \\
\end{array}$ & $\begin{array}{l}\text { AI } \\
\text { 3.min } \\
\end{array}$ & $\begin{array}{l}\text { AI } \\
\text { 5.min } \\
\end{array}$ \\
\hline \multicolumn{7}{|l|}{$\mathrm{mmHg}$ ) } \\
\hline th MAC & $84 \pm 17$ & $77 \pm 14$ & $82 \pm 14$ & $83 \pm 17$ & $79 \pm 13$ & $72 \pm 10$ \\
\hline toh & $82 \pm 10$ & $73 \pm 9$ & $3 \pm 14$ & $76 \pm 10$ & $71 \pm 9$ & $69 \pm 8$ \\
\hline e & 0.685 & 0.284 & 0.879 & 0.136 & 0.052 & 0.398 \\
\hline \multicolumn{7}{|l|}{ (beat $/ \mathrm{min}$} \\
\hline ath MAC & $98 \pm 14$ & $95 \pm 18$ & $99 \pm 17$ & $94 \pm 15$ & $93 \pm 18$ & $90 \pm 16$ \\
\hline atoh & $89 \pm 14$ & $97 \pm 17$ & $103 \pm 14$ & $100 \pm 17$ & $95 \pm 16$ & $93 \pm 17$ \\
\hline 1e & 0.056 & 0.465 & 0.408 & 0.253 & 0.756 & 0.499 \\
\hline \multicolumn{7}{|l|}{$\mathbf{m m H g})$} \\
\hline rath MAC & - & - & 398 & 404 & 393 & 384 \\
\hline ntoh & - & - & 397 & 405 & 394 & 374 \\
\hline ue & - & - & 0.783 & 0.922 & 0.912 & 0.390 \\
\hline Grath MAC & $99(98-100)$ & $100(98-100)$ & $100(98-100)$ & $99(98-100)$ & $100(98-100)$ & $99(98-$ \\
\hline sintosh & $100(98-100)$ & $99(98-100)$ & $99(98-100)$ & $99(98-100)$ & $99(98-100)$ & $99(97$ \\
\hline alue & 0.211 & 0.002 & 0.005 & 0.033 & 0.049 & 0.015 \\
\hline
\end{tabular}

Abbreviations: AI, after intübation; BP, blood pressure; ET, endtidal; SpO2, peripheral oxygen saturation. Data presented mean \pm standard deviation and median (minimum-maximum)

The assessment of the glottic view according to the C-L grade in the McGrath MAC video group and in the Macintosh laryngoscope group revealed no significant difference ( $p=0.738$ ). Comparison of the $\mathrm{C}-\mathrm{L}$ grade of the glottic view in the two groups also revealed no significant difference $(p=0.542)$. There was no significant difference when both groups were compared in terms of the intubation time and the need for neck extension $(p=0.779$ and $p=1.000$, respectively). All the intubations were performed successfully on the first attempt and no complications developed in either group (Table 3 ).

Table 3. Intubation characteristics with the McGrath MAC or Macintosh laryngoscope.

\begin{tabular}{lcll}
\hline & $\begin{array}{c}\text { McGrath MAC } \\
(\mathbf{n}=\mathbf{2 0})\end{array}$ & $\begin{array}{c}\text { Macintosh } \\
(\mathbf{n}=\mathbf{2 0})\end{array}$ & $\mathbf{p}$ value \\
\hline Duration of intubation & $20(10-50)$ & $20(15-36)$ & 0.779 \\
Neck extension needs & none & 1 & 1.000 \\
Direct C-L grade1 & $1(1-3)$ & $1(1-2)$ & 0.738 \\
Direct C-L grade2 & $1(1-3)$ & $1(1-3)$ & 0.542 \\
Failed intubation & none & none & - \\
Complication & none & none & - \\
\hline Abbreviations: Direct $C-L$ grade1, Cormack and Lehane grade \\
during initial laryngoscopy with the Macintosh laryngoscope; \\
Direct C-L grade2, Cormack and Lehane grade during \\
intubation with the McGrath MAC and Macintosh laryngoscope. \\
Data presented as median (minimum-maximum).
\end{tabular}

\section{DISCUSSION}

Spasticity and rigidity in patients with cerebral palsy occurs as a result of an imbalance in excitatory and inhibitory stimuli after the loss of all or a portion of the supraspinal inhibitory messengers ( $\gamma$-Aminobutyric acid [GABA]). A reduction in inhibitor stimuli at the nerve- muscle junction leads to the development of spasticity by increasing excitatory stimuli. ${ }^{19}$ General anesthetics result in the loss of spasticity by increasing the inhibition of GABA transmission. ${ }^{20}$ In addition, muscle relaxants used during general anesthesia contribute to muscle relaxation. However, relaxation of the joints of patients with joint contractures and dislocations is not possible under general anesthesia. This lack of relaxation cannot be detected in patients with cerebral palsy by a clinical examination before general anesthesia because of the extant spasticity. Although there are several tests for determining the degree of musculoskeletal abnormalities and disability with cerebral palsy, there are no methods to detect a difficult airway prior to the administration of general anesthesia. ${ }^{4}$ Therefore, patients with cerebral palsy are a high-risk difficult airway group.

A variety of equipment can be used in difficult airway management. In recent years, the efficacy of video laryngoscopes with various features has been investigated in different patient groups. ${ }^{10,20}$ There are many studies about its use in emergency services and the operating room where a difficult airway is frequently encountered. ${ }^{11,22}$ Liu et al. compared three different tracheal intubation techniques, the Shikani optical stylet, the GlideScope video laryngoscope, and a direct laryngoscope, in patients with a difficult airway who were scheduled to undergo thyroid tumor surgery. ${ }^{14}$ They stated that the Shikani optical stylet and GlideScope video laryngoscope shortened the duration of intubation, increasing the success rate and reducing the frequency of complications compared to direct laryngoscopy. Another recent study compared the efficacy of the CMAC video laryngoscope with that of the Macintosh laryngoscope in all patients admitted to the emergency department who received endotracheal intubation. ${ }^{11}$ The study reported that a video laryngoscope should be the first choice in all intubations applied in the 
emergency department. In this current study, all the intubations were carried out successfully in both groups, and no complications were recorded. Similar glottic images and intubation durations were obtained with the McGrath MAC video laryngoscope and the Macintosh laryngoscope. No additional advantages of using the video laryngoscope in patients with cerebral palsy were recorded.

In many studies with video laryngoscopes, difficulty in handling and directing the intubation tube has been reported. ${ }^{10,23}$ In this study, however, the video laryngoscope provided the same speed and quality of intubation as the Macintosh laryngoscope. There was no trauma or bleeding due to difficulty of use as the McGrath MAC video laryngoscope is easy to use and provides a cleart glottic image. ${ }^{25}$ Dupanovic et al. reported that careful preparation, styling and tube preparation before use would not extend the period of use. ${ }^{24}$ The McGrath MAC video laryngoscope provides a clear image of the vocal cords and laryngeal tissue on the liquid crystal display screen attached to the end of the handle and does not require forced alignment of the oral and pharyngeal axes in order to view the glottis. ${ }^{26}$ For this reason, Yokose et al. reported that video laryngoscopy would reduce the frequency of hypertension..$^{26}$ In this study, no significant difference was observed between the two laryngoscopes in terms of hemodynamics. İn this study McGrath video laryngoscope did not show any adverse effect on MAC hemodynamics.

Although our study included patients with cerebral palsy, in which musculoskeletal anomalies are common, sufficient muscle relaxation for intubation after general anesthesia was achieved in all patients. None of the patients had joint contractures or dislocations that could lead to difficult intubation. One patient in the Macintosh group required neck extension, but this did not affect the success or duration of the intubation. These results may partly be explained by the age of our patients (average age between 11 and 12 years of age) and the rehabilitation therapy these patients had undergone for musculoskeletal anomalies.

Our study has some limitations. All patients with cerebral palsy, with or without musculoskeletal deformities, were included in this study. Patients with the same level of disability could have been selected, as the same clinical tests were used to determine the degree of disability in cerebral palsy. ${ }^{4}$ In particular, patients with abnormalities that could make it difficult to provide an airway during general anesthesia could have been selected.

In conclusion, no difficulties in intubation were encountered in patients with cerebral palsy in either group, and the existing abnormalities of the patients did not affect the intubation success or complication rate. No additional advantage of using video laryngoscopy in patients with cerebral palsy was found.

\section{REFERENCES}

1. Dodge NN. Cerebral palsy: medical aspects. Pediatr Clin North Am 2008; 55:11891207.

2. Mc Donald RE, Avery DR. Dentistry fort the Child and Adolescent Saint Louis, Washington, D.C. Toronto, The C:V:Mosby Company 1988,s: 207-9,345-365

3. Nolan J, Chalkiadis GA, Low J, Olesch CA, Brown TC. Anaesthesia and pain management in cerebral palsy. Anaesthesia 2000; 55:32-41.

4. Richards CL, Malouin F. Cerebral palsy: definition, assessment and rehabilitation. Handb Clin Neurol 2013; 111:183-195.

5. Lerman J. Perioperative management of the paediatric patient with coexisting neuromuscular disease. Br J Anaesth 2011; 107:79-89. 
6. Cook TM, MacDougall-Davis SR. Complications and failure of airway management. Br J Anaesth 2012; 109:68-85.

7. Wass CT, Warner ME, Worrell GA, et al. Effect of general anesthesia in patients with cerebral palsy at the turn of the new millennium: a population-based study evaluating perioperative outcome and brief overview of anesthetic implications of this coexisting disease. J Child Neurol 2012; 27:859-866.

8. Ilyas S, Symons J, Bradley WP, et al. A prospective randomised controlled trial comparing tracheal intubation plus manual inline stabilisation of the cervical spine using the Macintoshlaryngoscope vs the McGrath(®) Series 5 videolaryngoscope. Anaesthesia 2014; 69:1345-1350.

9. Saricicek V, Mizrak A, Gul R, Goksu S, Cesur M. GlideScope video laryngoscopy use tracheal intubation in patients with ankylosing spondylitis: a series of four cases and literature review. J Clin Monit Comput 2014; 28:169-172. 10.Pournajafian AR, Ghodraty MR, Faiz SH, Rahimzadeh P, Goodarzynejad H, Dogmehchi E. Comparing GlideScope Video Laryngoscope and Macintosh Laryngoscope Regarding Hemodynamic Responses During Orotracheal Intubation: A Randomized Controlled Trial. Iran Red Crescent Med J 2014; 16:e12334.

11.Vassiliadis J, Tzannes A, Hitos K, Brimble J, Fogg T. Comparison of the C-MAC video laryngoscope with direct Macintosh laryngoscopy in the emergency department. Emerg Med Australas 2015; 27:119-125.

12.Aktas S, Atalay YO, Tugrul M. Predictive value of bedside tests for difficult intubations. Eur Rev Med Pharmacol Sci 2015; 19:15951599.

13. Cormack RS, Lehane J. Difficult tracheal intubation in obstetrics. Anaesthesia 1984; 39:1105-1111.

14. Brück $S$, Trautner $H$, Wolff $A$, et al. Comparison of the C-MAC( $\left({ }^{\circledR}\right)$ and GlideScope $(\circledR)$ videolaryngoscopes in patients with cervical spine disorders and immobilisation. Anaesthesia 2015; 70:160165 .

15.Liu L, Yue H, Li J. Comparison of three tracheal intubation techniques in thyroid tumor patients with a difficult airway: a randomized controlled trial. Med Princ Pract 2014; 23:448452.

16. Schälte $G$, Rex S, Henzler D. [Airway management]. Anaesthesist 2007; 56:837-855.

17.Lin WQ, Quan SB, Liu WJ, et al. Evaluation of the CEL-100 videolaryngoscope (TM) for double-lumen tracheal tube insertion after failure using the Macintosh laryngoscope. Anaesthesia 2012; 67:1232-1236.

18.Kanchi M, Nair HC, Banakal S, Murthy K, Murugesan C. Haemodynamic response to endotracheal intubation in coronary artery disease: Direct versus video laryngoscopy. Indian J Anaesth 2011; 55: 260-265

19. Albright AL, Pollack IF, Adelson PD: Principles and Practice of Pediatric Neurosurgery, 2nd edn. New York: Thieme, 2008.

20.Torri G. Inhalation anesthetics: a review. Minerva Anestesiol 2010; 76: 215-228.

21.Kilicaslan A, Topal A, Tavlan A, Erol A, Otelcioglu S. Effectiveness of the C-MAC video laryngoscope in the management of unexpected failed intubations. Braz $\mathbf{J}$ Anesthesiol 2014; 64:62-65.

22.Sun Y, Lu Y, Huang Y, Jiang H. Pediatric video laryngoscope versus direct laryngoscope: a meta-analysis of randomized controlled trials. Paediatr Anaesth 2014; 24:1056-1065.

23. Wetsch WA, Spelten O, Hellmich M, Carlitscheck M, Padosch SA, Lier H, Böttiger BW, Hinkelbein J. Comparison of different video laryngoscopes for emergency intubation in a standardized airway manikin with immobilized cervical spine by experienced anaesthetists. A randomized, controlled crossover trial. Resuscitation 2012; 83: 740745.

24.Dupanović M, Isaacson SA, Borovcanin Z, Jain S, Korten S, Karan S, Messing SP. Clinical comparison of two stylet angles for 
orotracheal intubation with the GlideScope video laryngoscope. J Clin Anesth 2010; 22:352-359.

25.Szarpak L, Karczewska K, Evrin T, Kurowski A, Czyzewski L. Comparison of intubation through the McGrath MAC, GlideScope, AirTraq, and Miller Laryngoscope by paramedics during child CPR: a randomized crossover manikin trial. Am J Emerg Med. 2015; 33:946-950.

26. Yokose M, Mihara T, Kuwahara S, Goto T. Effect of the McGRATH MAC® Video Laryngoscope on Hemodynamic Response during Tracheal Intubation: A Retrospective Study. PLoS One 2016; 11:e0155566.

\section{Corresponding Author}

Mustafa Erhan SARI

Ondokuz Mayis University,

Faculty of Dentistry,

Department of Pediatric Dentistry,

Samsun.

e-mail: dterhansari@hotmail.com

Tel: +90 36231219 19/4077

Fax: +90 3624576091 